\title{
Perplexed Writing: Towards a Possible Encounter between Criticism and Videodance
}

\author{
Susana Temperley \\ [Original translation by Mariana Di Silverio; \\ additional translation and editing by Valerie Klorman]
}

$\mathrm{T}$

he following words don't seek to talk about videodance, but about writing on videodance. Interest in this topic emerges from something that begins to take shape as a problem: videodance has found a space and has enjoyed prolific growth in Latin America but, nevertheless, it has not yet succeeded in awakening the interest of critics.

The fact is that criticism, one of the most important metadiscourses for the life of artistic genres and languages, ${ }^{1}$ can be defined as an extreme disconnect between the production and theorizing of videodance. The still incipient existence of critical texts becomes evident as compared with the vitality that its object of study has acquired. We can establish parameters for this situation by considering the context of the location of contemporary art in general, where the possibility of permanence and validity of the museum as a space for the circulation of works of art comprises one of the most current topics of discussion. In the case of criticism, conversely, the issue of validity as a means of circulation does not seem to take part in any discussion.

Thus, in view of criticism's palpable retreat, a question can be formulated in order to contribute to the opening of the debate: do formats of criticism and the questions criticism raises enable it to persist in functioning as a part of the metadiscursive device of contemporary art? The absence of criticism, still underhandedly, of hybrid arts such as videodance, might suggest something about this matter.

On the other hand, we encounter the writing of the artists themselves. The reflective word of the creators of videodance becomes more and more frequent (and fecund) and is oriented towards inquiring into their own pieces or theorizing about the language of videodance, summoning disciplines such as philosophy, epistemology, art history and even politics. The fact is that the different circuits that circulate works (especially festivals) have begun to open themselves up to parallel spaces, directed only at theoretical discussion which, for the moment, only occurs among the artists themselves.

Currently, the existence of these texts is of utmost importance since they constitute the only existing metadiscourse about videodance, while at the same time they point out a structural lack of writings external to the maelstrom of the production of pieces. Thus we can talk about theory coming from the field of artistic production as a means of expression that, though necessary, tends to generate a structural silence in the circuit of circulating works (despite fluid exchange through websites and blogs). Consequently, the possibility of a videodance "market" is still far off, and while many artists find themselves presenting their work independently or via festivals (more and more sophisticated and complete), as well as in itinerant exhibitions, the consumers of videodance that are generated by any of these means remain precisely the artists themselves. This is one of the crucial differences 
regarding video art in general which is, somehow, being exploited in more "profitable" circuits opened up by large corporations in the technology world (mainly telephone companies) through a neo-patronage that, while it may generate controversies, nevertheless seems to take over a place that was empty before.2

To summarize, there is a space within theory that is unoccupied, but there is also another, which has started to mature and become systematized. The crucial point lies in the proliferation of writings stemming from the field of artistic production itself, which implies certain advantages but which cannot replace criticism in the specificity of its role. ${ }^{3}$

The existence of criticism that opens up the field to a professional or at least renewed reflection seems to be crucial. For that reason, and in considering this topic, another question emerges: if a criticism in videodance existed, what role would it have to play in view of this complex and still controversial artistic language? In order to attempt to answer this question, we will have to take into account that the existence of criticism determines to a large extent the importance of a mode of artistic expression in culture, since it contributes to the designation of the status of what it criticizes and circumscribes it as an autonomous space of aesthetic effects.

\section{What Does it Mean to Be a Critic in Videodance?}

\section{Resolutions}

According to Danto, the aesthetic considerations that govern our relationship with the pieces, and even the concept of art itself, are not ahistorical and at the present time we find ourselves in a moment of radical change: "We should think about art after its end, as if we were emerging from the era of art into something else, the exact shape and structure of which remains to be understood" (26). ${ }^{4}$

The author accepts that art is paradigmatically unpredictable, but further, particularly in this moment, we would be facing a structure in which "everything is possible." Thus, contemporary art is too pluralistic in its intentions and realizations to allow it to be captured along a single dimension and, therefore, art criticism should be as pluralistic as post-historical art itself. ${ }^{5}$

How, then, do we understand "post-historical" criticism? Or, we should at least ask ourselves if it is possible to postulate lines of approach to contemporary works that allow us to continue defining criticism as a genre. ${ }^{6}$ If criticism has the task of determining the historical structure to which the piece it criticizes belongs, as well as the meanings it conveys and the intentions it satisfies, then there is an effect of uncertainty that becomes evident from the beginning, since we are facing an historical structure in which anything is possible. That is, we lack a master narrative that serves as a reference to critics to answer these questions.

\section{But Danto makes a proviso:}

Today anything is possible, in the sense that certain things were not possible for a European or an African in 1890. Still, we are locked in history. We cannot have the system of exclusionary beliefs that prevented artists in Europe from making idols and masks... But there are no forms today that are forbidden to us. The only thing that is forbidden to us is if they have the kind of meaning they had when they were forbidden to us. (65) 
According to this thesis, the emergence of a kind of criticism that is specialized in posthistorical languages such as videodance would confront an object of study characterized by freedom of form as well as newness and unpredictability regarding its "meaning," whereas criticism itself would be unthinkable outside of this "everything is possible" regime of beliefs.

This uncomfortable position that is presented to art critics of our time (either we call them contemporary or post-historical, it makes no difference) becomes evident in their own reflection. As the Mexican critic Cuauhtémoc Medina mentions:

Present-day art has to do with a territory that assumed (as an inheritance) a change in creative possibilities and in the dilemmas between those creative possibilities and discourses, images, sounds and social structures... Those of us who are inside this territory (criticism), do not understand more than those who are outside. Rather, we are open to the experience of having to build our relationship with these objects time after time, encountering pleasure in that moment of estrangement and learning.

Nobody teaches us how to develop it. The so-called experts become just as perplexed as everyone else. We probably cannot even do anything with what is being presented to us and precisely in the territory where we can establish dialogues between us, where we share our excitement, where the discourses are set up, is precisely that territory of perplexity...but we are not in a position to reject anything in the face of the condition of practices that are not held to any already known device?

In the face of this scene, videodance critics, upon assuming their role, would confront in first instance the need to "resolve" the dilemma of their own position, since it is possible that they may not be able to do/say anything with what is presented to them as an object of reflection. At the same time, the critic won't be in a position to reject it in order to return to a safe place, to the place of those art forms that are defined by a traditional device.

\subsection{Writing}

\subsection{Concepts}

Now then, writing is the medium where critics resolve their position. And right here another problem appears. Barthes describes the act of writing as a sort of paradoxically tragic gesture:

Without a doubt I can select any such mode of writing today, and in sodoing assert my freedom, aspire to a freshness or to a tradition; but I can no longer develop it for any period of time without gradually becoming a prisoner of someone else's words and even of my own. An obstinate residue, which comes from all previous modes of writing and even from the very past of my own writing, drowns the sound of my present words. Any written trace precipitates like a chemical element, at first transparent, innocent and neutral, in which mere duration gradually reveals a whole past in suspension of increasing density, like a cryptogram. $(25)^{8}$

The matter is that criticism of videodance confronts the task of "accompanying" and valorizing certain objects - which always live in a present characterized by the absence of limits in form - and as we have already seen, it is supposed to do it within that same historical structure. The critic must execute a writing of his own time, a time that is the same as the artist's (Barthes 9) but by means of signs that resist saying what has never been said before. 
Writing is a stale language which is self-contained and is in no way meant to entrust its own duration to a mobile series of approximations, but rather, on the contrary, it must impose, in both the unity of its signs and what is leftover by them, the image of a kind of speech that was constructed far before it came into existence. (Barthes 26)

So, to talk about something it is necessary to name it, and words designate, define and demarcate what is possible to be said. Art could be "anything" as defined by Danto, but criticism, even post-historical criticism, cannot talk about it in any kind of way. So, supposing that there exists or could exist someone so (irresponsibly) tenacious as to undertake the task of critiquing videodance, how could this individual analyze with limited language something that does not have any limits?

In other words, the criticism of videodance could be a kind of writing that arises from perplexity but that can never be imprecise or ambiguous without distorting its own character. With that being said, one aspect appears where it is possible to situate oneself in order to begin to escape from such difficulties: the permanent redefinition of concepts. ${ }^{9}$

It is already known that criticism will have to maintain a particular vision in order to assess different "types," whether those works center on technological experimentation (the eagerness for discoveries about new possibilities in movement and form, without entirely losing the aesthetic character), or on expressiveness, poetics and "humanistic" content or social context. Yet even above each one of these aesthetic lines, however, the critic will face, every time, a work that is different in its form, its grammaticality, in its unique being, that at the same time and without specifying how, is a part of a group (which a priori can only be characterized as "all the pieces like this one"). Here is where the writer will have to be able to propose beforehand a series of concepts through which something true can be said about a piece of videodance. So it is a matter of managing to develop concepts that are capable of being transformed according to each object and each position that writing may assume in the face of it.

The need for accuracy becomes abysmal (but not unthinkable), and for that reason, every time critics undertake a new object, they must subject the notions they use in their writings to permanent examination - from which the idea of a body intervenes in a videodance, in which aspects of the discipline are emphasized by choosing the term videodance and "dance for the camera", and even beyond that, because, certainly, it will be necessary to ask oneself about the meanings of device, movement and space that are present in the piece. And this, just to enter into the analysis - and many times, to create other new ones especially formulated for each case.

A signal then: the permanent reconceptualization of the notions that define and will continue to define the language of videodance becomes necessary, but before that, we must be able to create them.

\section{Common Places}

Now, we are faced with another problem to be solved: the freedom of the object tends to have repercussions on an abuse of the "common place" and on crystallized metaphors (catachresis). These appear as a symptom of the weakening of criticism in almost every other contemporary artistic language, from which videodance criticism still escapes simply because it lacks systematicity. Nevertheless, while they blur the writing, clichés 
and stereotypes are an intrinsic part of every reflection about art that emerges and seeks to mature, since they support the exchange of ideas and dialogue between critics and readers ${ }^{10}$ in the same way that floats are useful to the castaway.

Thus, common places and catachresis, are also being outlined in the case of writing about videodance, hence, pausing for a moment to think about them can turn out to be an interesting experience: What can be said through formulas such as: the "manipulation of the image," the "exploration of the landscape of dance," the "symbolic appropriation of space,"'dance experience,"'synthesis between dance and image,"'an involving experience... in which the audience becomes submerged," and the frequently cited "dialogue between camera and body"?

Crystallizations themselves that also crystallize a referent, common places, "are the effect, in their argumentative appeals, of the inertia of cultural memory" (Steimberg 4) and thus, they appear as a will that orients itself toward a past and therefore, in the opposite direction of the language that is its object and which is characterized by the complexity and the search for specificity in an unpredictable context situated somewhere between the present and the future.

Now another signal can be incorporated: the need for a permanent, alert position in the face of the very terms and phrases that define the language of criticism and that also act as rhetorical indexes of genre, while threatening their function as a period of time: saying something about an object that resists even being named.

\section{Taking Stock}

Defined by a double contradiction, one relating to the continued existence of a common place (which tends to eliminate particular reflection and complexity, while nothing can be communicated without it), and another one based on the ambiguity of concepts (the signs that limit what is possible to be said while there is no way to say anything without them), we glimpse a possible existence of a metadiscourse about videodance that seeks to endure beyond its own fatality: not only as writing but also as criticism, to the point of running the risk of finding itself in a place as tragic as that of silence in the face of a work of art.

The lines above give a report on a criticism of videodance that is still incipient, almost absent, but which already shows traces of its "post-historical" condition because it confronts the difficult if not impossible task of practicing the act of writing in order to assess something that often ends up being so novel that there are not yet any words to qualify it.

Thus, perplexity and writing are the places between which post-historical criticism and its object are developing. If videodance enables the perplexity of the spectator, it is fertilizing criticism's soil; and if criticism manages to change into something else-in such a way that it could modify the parameters that have historically defined it-its constitution as an accompanying metadiscourse of Videodance will be possible.

"The only reality, Foucault used to say, is not in words nor in things, but in objects. Objects are the result of that encounter between words and things" (Paraphrased in Danto 40). 


\section{Reflections on the Word of the Artist}

Koldobsky points out that:

... the last few decades of the $20^{\text {th }}$ Century are the result of redefinitions about works of art, the practice of art and its relationship with other social practices impelled in that period, that is, that from now on, the legacy of an accompanying word by an author does not come to be strange, beyond the form that it takes. ${ }^{11}$

This is, perhaps, an interesting point to explore in videodance in its historical context, and even, tangentially, the "post-historical" role ${ }^{12}$ of the videodance artist since whether it is about an accompanying word or the development of a novel function, the fact is that, at the present time, theory dedicated to reflection about this aesthetic practice finds itself almost exclusively under the control of the artists themselves.

Now then, I will refer here to the theory we could define as "auto-reflexive" and which is presented as a "reading deciphering key" for the piece itself but also as a guide for the comprehension of the language of videodance. If we take a panoramic view of Latin American writings of the last few years, two large groups emerge, oriented by a defined function (which can appear explicitly or not in the discourses themselves):

1. The works, belonging almost exclusively to audiovisual artists who navigate the waters of videodance, which propose, as a principal task, to inquire about the technical possibilities of the camera (framing, movement, editing effects, etc.), with regard to a time and a space tied to an object-body or to a body as a material that can be manipulated. These writings "organize" the techniques of images, tested out in their own productions, as well as the effects achieved by their application. They do so in such a way that they appear as a sort of "handbooks" legitimized in their own experience and directed towards the search for new possibilities of production and expansion of the limits of videodance above and beyond what has already been made and seen.

2. Those writings whose authorship corresponds mainly to individuals trained in the art of movement, which raise questions of epistemological and philosophical nature about the concept of the body, have a role as a subject or as an object in the always changing and troubled relationship with the camera, or the essence of videodance as a hybrid language, among others. In many of these essays, quotations about production itself and even the personal experience of the artist are included, either as a way of exemplifying the thesis involved or through paratextual reference. ${ }^{13}$ Regarding this last group: the paratextual reference of the piece itself generates an inversion in the relationship between theory and works, since the inclusion of quotes transforms writing into a complementary element to the videodance piece. Thus, it proves to be useful for deciphering the codes that allow us to understand which concept of body, movement and Videodance comes into play in it or at least, in the artist's thought in the course of the creation.

With that said, considering the permanence of these two main lines of theoretical reflection, we take as a reference the canonical institutional training (film school or dance academy) of the authors-artists who, nevertheless, navigate the seas of an elusive art, characterized by collage and fragmentation, and the inter- and trans-disciplinary.

So, this can give way to this question: Is the word of the artist really auto-reflexive? Or, in other words, is the artist occupying a place in theory that can be illustrated by the metaphor of 
"the snake that swallows its own tail"? The answer seems to be, initially, affirmative. Nevertheless, it stands out as a sign or as a symptom in the current theoretical production of videodance, the presence of a new model of artist-writers who, without denying the first gestation mould (having been educated in a "pure" art), situate themselves to write in that same undefined place which enables them to shape their pieces through a code of their own.

Thus, the growing tendency toward disciplinary crossings (in the case that we are currently engaged with-artists who leave the camera in order to be performers of their productions and the other way around) has repercussions on theoretical reflection and enables individuals to talk about their works, but "from another place." Not only, that is, from the other side of the street from their experience in image or dance, but moving away from the center of the scene (these subjects allow themselves to reflect on the others' work and even about the work of artists from other regions) always looking for something beyond themselves and beyond what the field offers to their ability to create.

\subsection{Taking Stock}

The writing of the videodance artist insinuates, sometimes, a subject that over the course of a canonical education has first acquired resources from other artistic disciplines, from theoretical reflection, and even from performances that do not appear to be linked in any way to the field of art and aesthetics.

This artist-writer is more a free inhabitant of the world and of languages than a disciplined scholar. So there is a theory, which belongs to this videodance creator-whose location cannot be entirely defined, riding on a horse between manifesto, criticism or simple literary expression - which "says much more" in that attempt to place his or her own artwork in a narrative whose existence is already marked by the absence of a master narrative.

\section{Notes}

1. Steimberg, Oscar. Semiótica de los medios masivos. Buenos Aires: Atuel, 1993. Print.

2. Another one is the bid made by some authors of videodance in featuring their pieces through independent film festivals, as is the case of 5 ( $\mathrm{cinco}$ ) by Jonathan Perel, present at BAFICI 2008 in the category of short film. In this case we can think about the incursion, which is to some extent successful, of this hybrid art in close discursive circuits but not in its own.

3. We refer to the role that criticism traditionally assumes, this being an essential part of the production, distribution and consumption chain of artistic products and, in this regard, being an audience builder. See Traversa, Oscar. Cine: el significante negado. Buenos Aires: Hachette, 1984. Print.

4. Danto, Arthur. Después del fin del arte. Buenos Aires: Paidós, 1997. Print.

5. Danto sketches the master narrative of the history of western art as an era of imitation followed by an era of ideology (in which philosophy explains art), followed by our post-historical era "... in which we can say, with qualification, anything goes" because it is the end of the master narrative.

6. Stemming from the operations it carries out, this is "to inform about the current state of art and to classify discourse focalized within a historical series both in what it resembles as well as in what it differs from it." Koldobsky, Daniela. "Sobre la conflictiva metadiscursividad de las artes visuales a partir de las vanguardias." AAS: Actas del VI Congreso de la Asociación Argentina de Semiótica. Buenos Aires, 2005. 3.

7. Medina, Cuauthémoc and Mar'a Minera. Cr'tica de Arte Contemporáneo. Conversación entre cr'ticos. Web. <www.letraslibres.com> (audio register).

8. Barthes, Roland. El Grado Cero de la Escritura: Nuevos Ensayos Cr'ticos. Buenos Aires: Siglo XXI Editores, 2005 (1972). Print. 
9. Paolo Fabbri points out that "Naturally, we cannot prevent the idea of the existence of some signs that in some cases are considered to be final. But that does not mean that there always exist final signs, such as words, the combination of which produces phrases or texts. Perhaps we can state the contrary: there only exist texts, texts of objects, not texts of words or texts of references, texts of complex objects, pieces of words, of gestures, of images, of sounds, of rhythms, etc, that is, groups that can be segmented according to need or urgency." See El giro semiótico. Barcelona: Gedisa, 1999. Print.

10. Incidentally, we can consider the characterization made by Oscar Steimberg regarding the discourse of historical avant-garde art, abundant in common places. The author refers to the fatal character already circumscribed in Aristotelian rhetoric, of the appeal to common places in argumentation. These are the reservoir of formulas that are already accepted and established in the public memory, to which the exhibitor should turn in order to situate the premises of rhetorical construction, and that, in the message of the avant-gardes, appears as an insurmountable internal contradiction. Steimberg, Oscar. "Vanguardia y lugar común." SYC 9/10 (1999). Buenos Aires.

11. Historical avant-garde movements risk the possibility of communication and audience building, insofar as the artistic discourse loses any predictability. Here lies the cause of the irruption into the artistic scene of manifestos; from there criticism will find new displays and will coexist with a growing and expanded accompanying discourse. Ibid. 7, pp. 3-4.

12. We can say, then, that the artist who also theorizes becomes adapted to the characterization made by Danto "Artists today are at the end of a history in which those narrative structures (those which end in Modernity) have played a role, and thus they can be distinguished from the artists that I have somewhat sentimentally imagined as those who first emerge as specialists in the early division of labor that enabled them as gifted individuals to take on the aesthetic responsibilities of society" (Danto 68).

13. See Genette, Gérard. Palimpsestos. La literatura en segundo grado. Madrid: Taurus, 1989. 